\title{
Hubungan Jenis Kecelakaan dengan Tipe Fraktur pada Fraktur Tulang Panjang Ekstremitas Bawah
}

\author{
Rianti Puti Ramadhani, ${ }^{1}$ Nurul Romadhona, ${ }^{2}$ M. Ahmad Djojosugito, ${ }^{3}$ \\ Dyana E.H., ${ }^{4}$ Dadang Rukanta ${ }^{5}$ \\ ${ }^{1}$ Program Studi Pendidikan Dokter, Fakultas Kedokteran Universitas Islam Bandung, \\ ${ }^{2}$ Bagian Ilmu Kesehatan Masyarakat, Universitas Islam Bandung, \\ 3.5Bagian Ortopedi, Fakultas Kedokteran Universitas Islam Bandung, \\ ${ }^{4}$ Bagian Radiologi, Fakultas Kedokteran Universitas Islam Bandung
}

\begin{abstract}
Abstrak
Cedera diprediksi menjadi penyebab utama kematian dan kecacatan dengan fraktur sebagai trauma utama, bahkan World Health Organization (WHO) telah menetapkan tahun 2000-2010 sebagai "The Bone and Joint Decade". Traumatic fracture dapat terjadi pada kecelakaan lalu lintas dan non-lalu lintas. Tipe fraktur berdasar atas hubungan dengan jaringan sekitarnya, antara fragmen tulang dan dunia luar (terbuka dan tertutup) dipengaruhi oleh beberapa faktor. Penelitian ini bertujuan mengetahui hubungan jenis kecelakaan dengan tipe fraktur yang terjadi pada fraktur tulang panjang ekstremitas bawah di Rumah Sakit Khusus Bedah Halmahera tahun 2017. Penelitian ini menggunakan metode analitik melalui cross sectional dan dilaksanakan selama Februari -Juni 2018. Pengambilan sampel menggunakan teknik simple random sampling dari data sekunder, yaitu rekam medik yang telah memenuhi kriteria inklusi dan tidak termasuk eksklusi dihitung menggunakan uji dua hipotesis didapatkan 84 orang. Hasil penelitian bivariat menggunakan uji chi-square didapatkan nilai signifikansi variabel jenis kecelakaan $(\mathrm{p}<0,001)$ lebih kecil daripada nilai signifikansi uji $(\mathrm{p}<0.05)$, terdapat perbedaan proporsi kejadian fraktur terbuka antara korban kecelakaan lalu lintas dan non-lalu lintas. Simpulan bahwa pada jenis kecelakaan dan tipe fraktur terdapat hubungan yang dipengaruhi oleh mekanisme cedera, kekuatan energi, tipe benda, dan kronologis kecelakaan.
\end{abstract}

Kata kunci: Fraktur tulang panjang, jenis kecelakaan, tipe fraktur

\section{Correlation between Type of Accidents and Type of Fractures in Lower-Extremity Long Bone Fractures}

\begin{abstract}
Injury predicted to be a leading cause of death and disability, with fractures as the majority of trauma, even the World Health Organization (WHO) has set 2000-2010 as "The Bone and Joint Decade". Traumatic fractures can be caused by the road traffic accidents and non traffic accidents. Fracture types in terms of its relation to the tissues involved, between the bone fragments and the outside (open and closed fractures) can be affected by several factors. This study purposed to determine the relation between types of accidents and types of fractures occurred in Halmahera Surgery Hospital 2017. This research uses analytic method with cross sectional study and was conducted in February-June 2018. Data sampling was taken by simple random sampling technique from medical records as secondary data, and the number of samples met both inclusion and exclution criteria calculated using the two hypotheses test resulted 84 people. The result of this research with chi-square test showed that the significance value of the type of accidents ( $p<0.001)$ was lesser than the test significance value $(p<0.05)$. This concluded that in this bivariate comparation research there is a difference between the type of accidents and low extremity long bone fracture types.
\end{abstract}

Key words: Long bone fracture, types of accidents, types of fractures

Korespondensi: Rianti Puti Ramadhani. Program Pendidikan Sarjana Kedokteran, Universitas Islam Bandung Jl. Tamansari No. 22, Kota Bandung, Provinsi Jawa Barat Telepon: (022) 2502924 HP: 081802232415 E-mail: riantiramadhani97@gmail.com 


\section{Pendahuluan}

Penyakit muskuloskeletal adalah salah satu penyakit yang banyak ditemukan di hampir seluruh dunia, bahkan World Health Organization (WHO) sudah menetapkan bahwa tahun 2000-2010 sebagai "The Bone and Joint Decade". ${ }^{1}$ Penyakit muskuloskeletal merupakan penyakit yang terjadi pada otot, tendon, persendian, atau tulang, antara lain nyeri pada tulang punggung serta fraktur. ${ }^{1}$ Fraktur itu dapat diakibatkan oleh penyakit degeneratif misalnya pada osteoporosis, keadaan patologis, dan yang disebabkan berbagai jenis kecelakaan (traumatic fracture) seperti kecelakaan domestik atau kecelakaan rumah tangga, kecelakaan kerja, kecelakaan olahraga, kecelakaan lalu lintas, dan sebagainya. $^{2}$

Traumatic fracture itu sudah diprediksi menjadi penyebab kecacatan dan kematian untuk beberapa dekade yang akan datang. ${ }^{3}$ Hasil Riset Kesehatan Dasar (Riskesdas) oleh Badan Penelitian dan Pengembangan Depkes RI tahun 2013 dinyatakan jenis trauma yang dapat menyebabkan fraktur antara lain kecelakaan non-lalu lintas, yaitu peristiwa terjatuh $(3,8 \%)$ dan karena tertusuk benda tajam atau tumpul $(1,7 \%)$ yang dapat terjadi pada kecelakaan domestik atau rumah tangga yang memiliki prevalensi tertinggi, kecelakaan kerja, dan kecelakaan olahraga. Selain pada kecelakaan non-lalu lintas, fraktur juga dapat disebabkan oleh peristiwa tabrakan pada kecelakaan lalu lintas $(8,5 \%) .{ }^{4}$

Pada penelitian lain persentase fraktur tulang panjang yang diakibatkan oleh kecelakaan non-lalu lintas 62,5\% dan yang disebabkan oleh kecelakaan lalu lintas sebesar 37,5\%..$^{5}$ Menurut Depkes RI tahun 2011, dari sekian banyak kasus fraktur di Indonesia, fraktur pada ekstremitas bawah akibat kecelakaan memiliki prevalensi yang paling tinggi di antara fraktur lainnya $(46,2 \%)$.

Secara umum fraktur tersebut dapat dibagi menjadi beberapa klasifikasi, salah satunya adalah berdasar atas hubungan tulang dengan jaringan sekitar, yaitu fraktur terbuka dan fraktur tertutup. Berdasar atas lokasi bagian tubuh yang terkena, fraktur ekstremitas bawah merupakan kontinuitas jaringan tulang yang terputus terjadi pada tulang yang menyusun ekstremitas bawah, dan tulang panjang ekstremitas bawah meliputi femur, tibia, dan fibula. ${ }^{6}$

Hasil survei tim Depkes RI 2013 mendapatkan $25 \%$ penderita fraktur mengalami kematian, $45 \%$ cacat fisik, $15 \%$ stres psikologis seperti cemas atau bahkan depresi, dan 10\% sembuh dengan baik. Berbagai jenis kecelakaan merupakan penyebab penting morbiditas, kecacatan fisik temporer atau permanen, dan bahkan kematian.

Berdasar atas uraian di atas dapat disimpulkan bahwa kecelakaan non-lalu lintas dan lalu lintas dapat mengakibatkan fraktur tulang panjang ekstremitas bagian bawah. Fraktur dengan klasifikasi yang berbeda memerlukan perhatian dan penanganan yang tepat untuk dapat menghindari akibat yang ditimbulkannya. Penanganan pertama yang tepat khususnya pada fraktur terbuka atau golden period sangat dibutuhkan untuk menghindari komplikasi infeksi. ${ }^{7,8}$ Penelitian ini bertujuan melihat hubungan antara jenis kecelakaan dan tipe fraktur tulang panjang ekstremitas bawah agar dapat dipergunakan sebagai infomasi untuk dapat menangani fraktur dengan tepat dan cepat.

\section{Metode}

Rancangan penelitian yang digunakan dalam penelitian ini adalah kuantitatif dengan metode observasional analitik melalui cross sectional study. Penelitian ini mengukur variabel independen dan dependen pada waktu yang bersamaan untuk melihat hubungan jenis kecelakaan, yaitu kecelakaan lalu lintas dan kecelakaan non-lalu lintas dengan tipe fraktur pada fraktur tulang panjang ekstremitas bawah di Rumah Sakit Khusus Bedah Halmahera tahun 2017.

Pengambilan data dilakukan di RS Khusus Bedah Halmahera selama Bulan Februari sampai April 2018 dengan melihat data-data sekunder rekam medik yang sesuai dengan kriteria inklusi dan tidak termasuk kriteria eksklusi didapatkan jumlah sampel 84 orang mempergunakan teknik simple random sampling. Analisis data mempergunakan metode uji chi-square karena variabel yang dipergunakan merupakan data kategorik tidak berpasangan menggunakan program statistical product and service solution for windows 24.0 dengan pada derajat kepercayaan 95\% dengan nilai $\mathrm{p} \leq 0,05$. Penelitian ini sudah lulus uji etik oleh Komite Etik Fakultas Kedokteran Universitas Islam Bandung yang ditandatangani pada tanggal 19 Maret 2018 dengan Nomor 327/Komite Etik.FK/III/2018.

\section{Hasil}

Subjek penelitian ini adalah pasien yang mengalami kecelakaan lalu lintas dan non-lalu lintas dengan fraktur tulang panjang pada ekstremitas bawah di Rumah Sakit Khusus Bedah Halmahera selama tahun 2017. Karakteristik subjek penelitian yang mengalami kecelakaan dengan fraktur tulang panjang ekstremitas bawah dapat dilihat pada Tabel 1 .

Tabel 1 Karakteristik Subjek yang Mengalami Kecelakaan dengan Fraktur Tulang Panjang Ekstremitas Bawah

\begin{tabular}{llcc}
\hline \multicolumn{1}{c}{ Variabel } & $\mathbf{n = 8 4}$ & \% \\
\hline Jenis & Lalu lintas & 42 & 50 \\
& Olahraga & 5 & 6 \\
& Domestik & 11 & 13 \\
& Kerja & 2 & 2 \\
& Lain-lain & 24 & 29 \\
Jenis fraktur & Tertutup & 71 & 85 \\
& Terbuka & 13 & 15 \\
Jenis kelamin & Laki-laki & 61 & 73 \\
& Perempuan & 23 & 27 \\
Usia (tahun) & Minimum & 3 & \\
& Maksimum & 84 & \\
& Median & 42 & \\
\hline
\end{tabular}


Tabel 2 Hubungan Jenis Kecelakaan dengan Tipe Fraktur pada Pasien Fraktur Tulang Panjang Ekstremitas Bawah

\begin{tabular}{lccc}
\hline \multirow{2}{*}{$\begin{array}{c}\text { Tipe } \\
\text { Kecelakaan }\end{array}$} & \multicolumn{2}{c}{ Jenis Fraktur } & Nilai p \\
\cline { 2 - 3 } & Tertutup & Terbuka & \\
\hline Non-lalu lintas & $42(100 \%)$ & $0(0 \%)$ & $<0,001$ \\
Lalu lintas & $29(69 \%)$ & $13(31 \%)$ & \\
Jumlah & $71(85 \%)$ & $13(15 \%)$ & \\
\hline
\end{tabular}

Pasien yang mengalami kecelakaan lalu lintas dan non-lalu lintas yang mengalami fraktur tertutup (85\%) lebih banyak dibanding dengan fraktur terbuka (Tabel 1).

Hasil uji chi square terdapat perbedaan proporsi kejadian fraktur yang bermakna $(\mathrm{p}<0,001)$ antara tipe kecelakaan dan jenis fraktur terbuka atau tertutup fraktur tulang panjang ekstremitas bawah di Rumah Sakit Khusus Bedah Halmahera tahun 2017. Fraktur terbuka pada kecelakaan non-lalu lintas berisi angka nol yang mengakibatkan estimasi risiko odd ratio yang digunakan untuk mengukur besar asosiasi antara variabel independent (kecelakaan lalu lintas dan nonlalu lintas) dan variabel dependent (fraktur terbuka dan tertutup) tidak dapat dihitung (Tabel 2).

\section{Pembahasan}

Fraktur merupakan kontinuitas tulang atau kesatuan struktur tulang terputus yang dapat merupakan retak, remah, atau bagian korteks pecah. Tipe fraktur berdasar atas hubungan tulang dengan jaringan di sekitarnya dibagi menjadi fraktur terbuka dan fraktur tertutup. Fraktur terbuka adalah fraktur yang merusak jaringan kulit sehingga terdapat hubungan fragmen tulang dengan dunia luar, sedangkan fraktur tertutup merupakan fraktur tanpa hubungan antara fragmen tulang dan dunia luar. Fraktur yang disebabkan oleh peristiwa trauma (traumatic fracture) dapat terjadi pada kecelakaan lalu lintas maupun non-lalu lintas. ${ }^{6}$

Tabel 2 menunjukkan terdapat hubungan antara jenis kecelakaan dan tipe fraktur. Hal ini disebabkan oleh faktor-faktor yang dapat memengaruhi mekanisme fraktur pada kecelakaan, antara lain mekanisme cedera (direct, indirect force), besar kekuatan energi (lowenergy, high-energy), tipe benda yang terlibat dalam kejadian fraktur (tajam dan tumpul), serta kronologis tertentu dalam suatu kecelakaan..$^{9,10}$

Fraktur yang tertutup diakibatkan oleh mekanisme cedera dan kekuatan energi yang tidak terlalu besar, tidak terdapat perlibatan benda tajam, dan kronologis seperti terjatuh, terkilir, dan tertimpa benda berat yang terjadi pada kecelakaan non-lalu lintas. ${ }^{10}$ Sementara fraktur terbuka diakibatkan oleh mekanisme direct force dengan kekuatan high-energy dan keterlibatan benda tajam seperti badan kendaraan yang lebih sering terjadi pada kecelakaan lalu lintas.

Pada penelitian ini ternyata kecelakaan lalu lintas yang mengakibatkan fraktur yang tertutup lebih besar daripada fraktur terbuka. Berbeda dengan penelitian sebelumnya, pada kecelakaan lalu lintas angka kejadian fraktur terbuka lebih tinggi dibanding dengan fraktur tertutup. ${ }^{11}$ Hal ini mungkin disebabkan oleh faktorfaktor seperti mekanisme cedera serta kekuatan energi yang tidak terlalu besar, kurang keterlibatan benda tajam, serta kronologis tertentu seperti posisi korban dan jenis kendaraan pada kecelakaan lalu lintas pada penelitian ini memengaruhi tipe fraktur.

Selain kekuatan tekanan, mekanisme trauma dan jenis benda tajam atau tumpul terdapat beberapa faktor risiko yang memengaruhi fraktur tulang panjang pada kejadian kecelakaan, antara lain usia, jenis kelamin, kekuatan otot, dan juga kekuatan struktur tulang per individu. Usia anak dan remaja lebih sering mengalami fraktur tulang panjang karena proses pertumbuhan terjadi pada lempeng fisis yang lebih rapuh. Usia tua sering disertai dengan keadaan patologis tulang atau kepadatan tulang yang berkurang. Perempuan lebih mudah mengalami fraktur pada usia lansia yang dipengaruhi oleh proses pengeroposan tulang. Namun, laki-laki pada penelitian ini lebih sering mengalami fraktur. Hal ini merupakan faktor-faktor yang mungkin menjadi variabel perancu yang tidak diteliti pada penelitian ini.

\section{Simpulan}

Terdapat hubungan antara jenis kecelakaan dan tipe fraktur pada pasien fraktur tulang panjang ekstremitas bawah di Rumah Sakit Khusus Bedah Halmahera tahun 2017.

\section{Ucapan Terima Kasih}

Ucapan terima kasih kepada Pimpinan RS Khusus Bedah Halmahera yang telah membantu pelaksanaan penelitian ini.

\section{Daftar Pustaka}

1. Woolf AD. The bone and joint decade 2000-2010. Ann Rheum Dis. 2000 Feb;59(2):81-2.

2. Triono $\mathrm{P}$, Murinto. Aplikasi pengolahan citra untuk mendeteksi fraktur tulang dengan metode deteksi tepi. J Inform. 2015;9(2):1115-23.

3. Storheim K, Zwart JA. Musculoskeletal disorders and the Global Burden of Disease study. Ann Rheum Dis. 2014 Jun 1;73(6):949-50.

4. Riset Kesehatan Dasar (Riskesdas) 2013 (diunduh 20 Agustus 2018). Tersedia dari: http://www. depkes.go.id/resources/download/general/ HasilRiskesdas 2013.

5. Rennie L, Court-Brown CM, Mok JY, Beattie TF. The epidemiology of fractures in children. Injury. 2007;38(3):913-22.

6. Solomon L, Warwick D, Nayagam S. Apley's system of orthopaedics and fractures (9th Edition). Malaysian Orthopaedic J. 2010;4(3):39.

7. Meling T, Harboe K, Søreide K. Incidence of traumatic long-bone fractures requiring inhospital management: a prospective age-and gender-specific analysis of 4890 fractures. Injury. 2009;40(11):1212-9. 
8. Gustilo RB, Mendoza RM, Williams DN. Problems in the management of type III (severe) open fractures: a new classification of type III open fractures. J Trauma. 1984 Aug;24(8):742-6.

9. Renninger $\mathrm{CH}$, Cochran $\mathrm{G}$, Tompane T, Bellamy J, Kuhn K. Injury characteristics of low-energy lisfranc injuries compared with high-energy injuries. Foot Ankle Int. 2017 Sep 10;38(9):964-9. 10. López-Arquillos A, Rubio-Romero JC. Analysis of workplace accidents in automotive repair workshops in Spain. Saf Health Work. 2016 Sep;7(3):231-6.

11. Court-Brown CM, Rimmer S, Prakash U, McQueen MM.. The epidemiology of open long bone fractures. Injury. 1998 Sep;29(7):529-34. 